\title{
PÁLNÉ KOVÁCS ILONA (SZERK.): A POLITIKA ÚJ SZÍNTERE A RÉGIÓ
}

\author{
(Századvég, Pécs-Budapest, 2009. 242 o.)
}

\section{DÁVID GÉZA}

A regionalizmus magyarországi bölcsőjeként számon tartott Pécsett készült kötet a politika új dimenziójaként veszi vizsgálat alá a régiót. A regionális szintű politika empirikus kutatásának sem a magyar, sem a nyugat-európai társadalomtudományokban nincs jelentős hagyománya, ezért úttörő feladatra vállalkoztak a szerzők. A kötet a PTE BTK Politikai Tanulmányok Tanszéke és doktoriskolai programja által 2005 és 2008 között végzett OTKA kutatás eredményeit dolgozza fel, felhasználva a DélDunántúlon - elsősorban az MTA Regionális Kutatások Központja által - végzett korábbi regionális kutatások tapasztalatait is. A politika regionális dimenzióban történö vizsgálatát az elmúlt évek kormányzati decentralizációs politikája (és annak részleges kudarca) is szuikségessé teszi. A kutatás tárgyaként több szempontból is kimondottan szerencsés választás a Dél-Dunántúl, hiszen ebben a régióban vannak a legrégebbi és kifejezetten helyi gyökerei a regionális együttmüködésnek, valamint egy erősen leszakadó régióról beszélhetünk, ami a források felhasználásához szüikségessé teszi a sikeres együttmüködést, a kihívásokhoz való alkalmazkodást. A kötet bevezetőjében Pálné Kovács Ilona átfogó képet ad mind a kutatás elméleti és módszertani hátteréről, mind pedig a vizsgált régió társadalmi, gazdasági sajátosságairól, valamint a regionális együttmüködés elözményeiről. A kutatás interdiszciplináris jellegéből adódóan a kötet szerzői más és más területen, különböző megközelítésben vizsgálták a regionalizációban elért eredményeket.

Schmidt Andrea a közszolgáltatásokat nyújtó intézményrendszer regionális szervezödését elemezte, megvizsgálva az energiaszektor, a pénzügyi szolgáltatások, a közlekedés és logisztika, a kommunális szolgáltatások, az egészségügy, a szociális ellátás, az oktatás, valamint a $\mathrm{K}+\mathrm{F}$ szolgáltatások regionális integrációit. Rendkívül aktuális a régió közlekedési helyzetének elemzése, különösen a vasúti és az autóbusz-közlekedés jelenleg is zajló összehangolási, racionalizálási kísérlete fényében.

Vadál Ildikó a területi államigazgatási rendszer dilemmáiról írt tanulmányában a 2007. január 1-jén életbe lépett reform tapasztalatait dolgozta fel. Ahogy az elmúlt évek oly sok reformkísérlete, a területi államigazgatási szervek 2007. évi reformja is felemásra sikeredett, ami nagyrészt az egységes kormányzati koncepció hiányával magyarázható (akárcsak az előző, 1996. évi reform esetén). Az átalakítás elsősorban az illetékességi területeket érintette, központi szintről regionális szintre nem telepítettek feladat- és hatásköröket. Vadál Ildikó nemcsak külsö szemlélőként írja le az átalakítás 
folyamatát, de a reformban érintett szervek vezetőinek tapasztalatait, véleményét is (kellő kritikával) felhasználja az előnyök és a hátrányok számbavételénél.

A top down és a bottom up regionalizációs folyamatoknak megfelelóen az államigazgatási szervezetrendszer átalakítása mellett elengedhetetlen a régióban működő civil szervezetek együttmüködésének vizsgálata. Ezt Glied Viktor teszi meg „A civil partnerség szerepe a regionális döntéshozatali folyamatokban" címủ tanulmányában. A civil együttműködés jogi szabályozásának áttekintése után megyei és regionális szinten vizsgálja a civil szektor hálózatosodását. Az Európai Unióhoz való csatlakozást követően új lendületet kapott a civil hálózatok kialakulása, ugyanakkor a forrásokért zajló verseny is kiélezetté vált. A régió számos civil szervezetének vezetőjével készült interjúk alapján Glied Viktor egy fokozatosan fejlődő, egyre aktívabb civil hálózati rendszer képét tárja elénk.

A régiót akciótérként értelmezve vizsgálta a meghatározó szereplök hálózatosodását Pálné Kovács Ilona. Tanulmánya - „Regionális hálózatok a Dél-Dunántúlon”úttörő vállalkozás abban az értelemben, hogy a hazai szakirodalom eddig nem fordított figyelmet a regionális szereplők közötti kapcsolatok értékelésére. Az elemzés nem pillanatképet mutat a régióról, hanem a 2008-ban zárult kutatás tapasztalatait veti össze egy korábbi, szintén részben a szerző által végzett 2003-as OTKAkutatás eredményeivel, így kimutathatóvá válnak a regionális szereplök közötti kapcsolati hálóban történt változások is. Mindezt nagyon hatásos, az aktorok egymáshoz való viszonyrendszerét jól érzékeltetö, de mégis könnyen értelmezhető ábrákon keresztül mutatja be a szerzỏ. Különös kép rajzolódik ki a szektorok közötti kapcsolatokról, kiderül például, hogy a megkérdezett intézményi szereplők kapcsolatrendszere a régión kívül sürübb, mint azon belül, de ugyanilyen érdekes az egyetemek viszonylagos elszigeteltsége. A 2003-as időszakhoz képest a legjelentősebb változás a megyei szintű fejlesztési tanácsok visszaszorulása, de továbbra is meghatározó a regionális szintü területfejlesztési intézmények kapcsolatrendszere.

A választott regionális területi önkormányzatok kialakítására tett kísérlet bukása miatt továbbra is a regionális fejlesztési tanácsok töltik be a regionalizáció emblematikus intézményének szerepét. Az elmúlt évtizedben az egyre részletesebb szabályozás mellett erőteljes centralizáció is végbement, a tanácsok autonómiája minimálisra zsugorodott. A Dél-dunántúli Regionális Fejlesztési Tanács müködési tapasztalatait és regionalizációban betöltött szerepét vizsgáló tanulmányában Hahn Hajnalka a tanács 2004. május és 2008. december közötti üléseinek jegyzőkönyveit feldolgozva mutatja be a jellemzö konfliktusokat, érdekellentéteket. A régió egységes érdeke háttérbe szorul mind a központi, mind a helyi érdekekkel szemben. A tanács tagjainak gondolkodásában sokkal erősebben van jelen a lokális vagy akár megyei kötődés, mint a regionális identitás.

A regionalizáció folyamatában és különösen a regionális identitás kialakulásában nemcsak a politikusok játszanak meghatározó szerepet, hanem az egész elit. A régió elitjének regionális identitását vizsgálta Kákai László a három megyében végzett 200 kérdőíves interjú segítségével. Mivel Magyarországon a regionalizmusnak nincsenek hagyományai, a területi kötődést elsősorban a települések, illetve a megyék szintjén 
Tér és Társadalom 23. évf. 2009/4. 245-248. p.

lehetséges vizsgálni, ezért a szerző az erre irányuló korábbi saját kutatási eredményeit hasonlítja össze jelen vizsgálatának eredményeivel. Ennek során arra a nem meglepő eredményre jut, hogy még az elit esetében is inkább csak megyei identitásról beszélhetünk, semmint régió-tudatról. Az interjúk összesített és számszerüsített eredményeinek rövid leírása, valamint diagramokban és táblázatokban történő bemutatása mellett magát a kérdöívet is tartalmazza a kötet. A kérdőív átlapozásakor láthatjuk, hogy annak csupán az első része kérdez rá a területi kötődésre, míg a második blokk a területi reformmal kapcsolatos véleményéről, a harmadik blokk pedig az intézményi kapcsolathálózatról kérdezi a regionális elit tagjait. A kérdőív második részének eredményeit jól áttekinthető táblázatok segítségével Pálné Kovács Ilona második tanulmánya mutatja be részletesen (Regionális elit és a területi reform). (A harmadik blokk eredményeit a korábban ismertetett Regionális hálózatok a DélDunántúlon címú fejezet tárgyalja.) Az eredmények nagyrészt megfelelnek a várakozásoknak, egyáltalán nem meglepőek. A regionális reformot általánosságban a többség támogatja, és abban is egyetértés tapasztalható, hogy a sikeres végrehajtásához politikai konszenzust, alaposabb elökészítést és hosszabb időt tartanak sziikségesnek.

Szintén a regionális identitást vizsgálta a Kern Tamás és Koller Inez által végzett empirikus kutatás. Sajtóelemzésük során a régió három megyei napilapjában (Dunántúli Napló, Somogyi Hírlap, Tolnai Népújság) három évben (1998, 2002, 2006) vizsgálták meg a régiókhoz, regionalizmushoz kapcsolódó cikkeket. Eredményeik több szempontból magukat a kutatókat is meglepték, ugyanis a vizsgálat megkezdésekor felállított hipotéziseiket nem vagy csak alig tudták igazolni. A folyamatosan csökkenő cikkmennyiség nem mutat fel specializáltabb arculatot, nem a politikai, közigazgatási jellegü regionalizációról, a regionális civil egyuittmüködésről tudósít, hanem leginkább csak a területfejlesztés és a regionális gazdasági együttmúködés témakörére szorítkozik. A megyei napilapok nem képesek (vagy nem hajlandók) regionális kohéziót teremteni, nincs regionális identitásteremtő szerepük.

Persze felmerülhet bennünk a kérdés, hogy miért van egyáltalán szükségünk régióra, ha ennyire nehezen tudjuk tartalommal megtölteni? A regionalizmus hagyományainak hiányában az Európai Unió elvárásainak megfelelve alakítottuk ki a tervezésistatisztikai régiókat (a NUTS 2-es szintet), melyeknek most identitást szeretnénk adni, ezáltal is elósegítve európai regionális politikában való hatékony részvételiuket. Ebben az aspektusban vizsgálta Tuka Ágnes a Dél-dunántúli régió uniós kapcsolatrendszerét, érdekérvényesítő képességét. A regionális érdekérvényesítés legfőbb fórumaként létrehozott Régiók Bizottságában (CoR) a magyar delegáció vezetőjének tapasztalatai szerint nem annyira egy-egy régió, hanem inkább az ország érdekében lehet lobbizni. Az érdekképviselet egy másik formáját jelentette 2006-tól a régió közvetlen képviselete Brüsszelben (a regionális fejlesztési ügynökségek egy-egy munkatársának kiküldésével), ami azonban csak rövid ideig volt müködőképes.

Végigolvasva a kötetet választ kapunk arra a kérdésre, hogy beszélhetünk-e egyáltalán a régióról, mint a politika új színteréről (amennyiben kérdésként fogjuk fel a kötet címét). Hadd válaszoljuk ezt meg Pálné Kovács Ilona szavaival, ami jól összegzi a tanulmányok konklúzióit: „...a régió még mindig inkább a megyékből 
összerakott mesterséges egység, semmint a megyéktöl elszakadó összetartó, egy vagy kevés földrajzi központú hálózat". A tanulmánykötet a Dél-dunántúli régió példáján keresztiil tudományos igényességgel mutatja be a magyarországi regionalizáció pillanatnyi állapotát, az eddig elért - gyakran felemás - eredményeket. Mindazok számára tanulságos lehet a kötet forgatása, akik a regionalizáció kérdéskörével foglalkoznak, vagy egyszerủen csak érdeklődnek a Dél-dunántúli régió iránt. Kuilönösen ajánlanám a kötetet a regionális elit figyelmébe, nemcsak azért, mert a kutatás alanyaiként jelennek meg, de egyben aktív formálói (lehetnének) a hazai régióépítésnek. Mindössze egy, ám néha kimondottan zavaró hibát lehet találni a kötetben, a korrektor vagy a tördelő figyelmetlenségének tulajdonítható sorközi elválasztásokat, ami sajnos az egész könyvet végigkíséri vissza-visszatérö hibaként, ám ez mit sem von le a tartalom tudományos színvonalából. A különböző vizsgálati megközelítések alapján készült tanulmányok végül koherens egésszé állnak össze, átfogó képet nyújtva a régióról. Külön érdemes kiemelni, hogy több kutató is eddig csak kevéssé vagy egyáltalán nem alkalmazott szempontok alapján vizsgálta a régiót. Mint ahogy a kötetben számos helyen összehasonlítási alapként megjelennek korábbi kutatások eredményei, ez a munka - mely alapvetöen a legfrissebb eredményeket összegzi - is kiindulópontként szolgálhat további elemzések számára. A regionalizáció hazai szakirodalma egy újabb értékes, folytatásra ítélt müvel bővült általa. 